\begin{abstract}
HETEROCYCLES, Vol. 91, No. 5, 2015, pp. 1036 - 1041. @ 2015 The Japan Institute of Heterocyclic Chemistry Received, 12th February, 2015, Accepted, 24th March, 2015, Published online, 8th April, 2015 DOI: $10.3987 / C O M-15-13193$
\end{abstract}

\title{
NEW ANTI-OXIDATIVE COMPOUNDS FROM RHINACANTHUS NASUTUS
}

\section{Ryuichiro Suzuki, ${ }^{a}$ Hiroshi Sakagami, ${ }^{b}$ and Yoshiaki Shirataki ${ }^{a *}$}

${ }^{a}$ Faculty of Pharmaceutical Sciences, Josai University, Sakado, Saitama, 350-0295, Japan; E-mail: shiratak@josai.ac.jp, ${ }^{b}$ Divisions of Pharmacology, Meikai University School of Dentistry, Sakado, Saitama, Japan

\begin{abstract}
Two new antioxidative compounds were isolated from methanolic extract of root of the Rhinacanthus nasutus. These chemical structures were elucidated by analysis of 1D and 2D NMR spectra including MS. Antioxidant activities of these isolates were determined by DPPH radical scavenging activity test. As the results, antioxidant activities of these isolates were comparative to Trolox used as a positive control. These isolates showed little or no detectable cytotoxicity against both human cancerous and normal cells.
\end{abstract}

The shrub of Rhinacanthus nasutus (L.) Kurz (Acanthaceae) is widely distributed in Southeast Asian countries and used for the treatment of pneumonia, diabetes, hypertension and skin diseases. ${ }^{1}$ The root and aerial parts of this plant contain naphthoquinone esters, such as rhinacanthin $\mathrm{C}, \mathrm{D}, \mathrm{N}$ and $\mathrm{Q}$, which exhibit apoptosis-inducing, ${ }^{2-5}$ antitumor, antiviral, ${ }^{6}$ antiallergic ${ }^{7}$ and anti-inflammatory activities. ${ }^{8,9}$ Furthermore, we reported that rhinacanthin $\mathrm{C}$ isolated from this material showed potent inhibition of the RANKL (receptor activator of NF- $\mathrm{B}$ ligand ) -stimulated osteoclastogenesis. ${ }^{10}$ In this research we separated the $n$-butanol soluble fraction prepared from methanol extract of $R$. nasutus to isolate two new compounds (1 and 2). Figure 1 showed the structures of $\mathbf{1}$ and $\mathbf{2}$ and their ${ }^{1} \mathrm{H}$ and ${ }^{13} \mathrm{C}$ NMR spectral data were listed in Table 1. DPPH radical scavenging activities of isolates were examined according to published methods. ${ }^{11,12} \mathbf{1}$ and $\mathbf{2}$ showed potent scavenging activities toward the DPPH radical. Furthermore, $\mathbf{1}$ and $\mathbf{2}$ did not show cytotoxicity against human oral squamous cell carcinoma cell lines (HSC-3 and HSC-4), human immortalized skin keratinocyte cell line (HaCaT) and human normal oral cells [gingival fibroblast (HGF), pulp cell (HPC) and periodontal ligament fibroblast (HPLF)].

Compound 1 was obtained as bluish amorphous solid. Its molecular formula was decided as $\mathrm{C}_{13} \mathrm{H}_{17} \mathrm{NO}_{6}$ by HRFABMS $m / z 284.1138[\mathrm{M}+\mathrm{H}]^{+}$. The ${ }^{1} \mathrm{H}$ NMR spectrum of $\mathbf{1}$ displayed signals for the presence of a 
methine group at $\delta_{\mathrm{H}} 5.28(\mathrm{dd}, 1.2,4.8,1 \mathrm{H})$, and two nonequivalent geminal methylene protons at $\delta_{\mathrm{H}} 2.10$ $(\mathrm{dd}, 2.0,10.7,1 \mathrm{H})$ and $\delta_{\mathrm{H}} 2.40$ (overlapped with $\left.\mathrm{H}-4\right)$ and $\delta_{\mathrm{H}} 2.40$ (overlapped with $\mathrm{H}-3$ ) and $\delta_{\mathrm{H}} 2.65$ (m, $1 \mathrm{H})$. In aromatic field, singlet signal at $\delta_{\mathrm{H}} 6.54(\mathrm{~s}, 1 \mathrm{H})$ were observed. Furthermore, three methoxy signals appeared at $\delta_{\mathrm{H}} 3.24(\mathrm{~s}, 3 \mathrm{H}), \delta_{\mathrm{H}} 3.77(\mathrm{~s}, 3 \mathrm{H})$ and $\delta_{\mathrm{H}} 3.82(\mathrm{~s}, 3 \mathrm{H})$. The signal at $\delta_{\mathrm{H}} 5.28(\mathrm{dd}, 1.2,4.8$, $1 \mathrm{H}$ ) was coupled in the COSY spectrum to nonequivalent geminal protons at $\delta_{\mathrm{H}} 2.40$ (overlapped with $\mathrm{H}-3)$ and $\delta_{\mathrm{H}} 2.65(\mathrm{~m}, 1 \mathrm{H})$. These nonequivalent geminal signals were further coupled with another nonequivalent geminal signals at $\delta_{\mathrm{H}} 2.10(\mathrm{dd}, 2.0,10.7,1 \mathrm{H})$ and $\delta_{\mathrm{H}} 2.40$ (overlapped with $\left.\mathrm{H}-4\right)$. In ${ }^{13} \mathrm{C}$ NMR spectrum thirteen signals were detected, composed of a carbonyl carbon at $\delta_{\mathrm{C}} 178.2$, six $s p^{2}$-hybridized methine carbon signals at $\delta_{\mathrm{C}} 109.0, \delta_{\mathrm{C}} 115.7, \delta_{\mathrm{C}} 138.3, \delta_{\mathrm{C}} 141.9, \delta_{\mathrm{C}} 142.5$ and $\delta_{\mathrm{C}} 142.9$, two $s p^{3}$-hybridized methylene carbons at $\delta_{\mathrm{C}} 26.5$ and $\delta_{\mathrm{C}} 30.2$ and an $s p^{3}$-hybridized methine carbon signal at $\delta_{\mathrm{C}}$ 94.7. Meanwhile, HMBC correlations of $\delta_{\mathrm{H}} 5.28(\mathrm{dd}, 1.2,4.8,1 \mathrm{H})$ at $\mathrm{H}-5$ with $\delta_{\mathrm{C}} 178.2$ at $\mathrm{C}-2$ and the correlations of $\delta_{\mathrm{H}} 2.10(\mathrm{dd}, 2.0,10.7,1 \mathrm{H})$ at $\mathrm{H}-3$ with $\delta_{\mathrm{C}} 178.2$ at $\mathrm{C}-2, \delta_{\mathrm{C}} 30.2$ at $\mathrm{C}-4$ and $\delta_{\mathrm{C}}$ 94.7 at C-5 were observed (Figure 2). Methoxy protons at $\delta_{\mathrm{H}} 3.24(\mathrm{~s}, 3 \mathrm{H}), \delta_{\mathrm{H}} 3.77(\mathrm{~s}, 3 \mathrm{H})$ and $\delta_{\mathrm{H}} 3.82$ $(3 \mathrm{H}, \mathrm{s})$ showed also interactions with carbons at $\delta_{\mathrm{C}} 56.0, \delta_{\mathrm{C}} 57.4$ and $\delta_{\mathrm{C}} 61.3$, respectively in the HMBC spectrum. ${ }^{13} \mathrm{C}$ NMR chemical shifts and HMBC correlations along with published data ${ }^{13,14}$ indicated that 1 was composed of an nitrogen atom contained five-membered ring (pyrrolidinone) and one aromatic ring highly substituted hydroxy and methoxy functions. Finally the connection of pyrrolidinone ring and benzene ring was confirmed based on the results of NOESY of $\mathbf{1}$ as shown in Figure 2. NOESY correlation of aromatic proton attributed at $\mathrm{H}-11\left(\delta_{\mathrm{H}} 6.54, \mathrm{~s}, 1 \mathrm{H}\right)$ and methine proton $\left(\delta_{\mathrm{H}} 5.28, \mathrm{dd}, 1.2,4.8\right.$, 1H) connected with C-5 was observed. Positions of methoxy and hydroxy group connected on benzene ring however were elucidated by HMBC and NOESY correlation including ${ }^{13} \mathrm{C} N \mathrm{NM}$ spectral data, methoxy group connected at C-7 position might be substituted to hydroxy group. To confirm the position of hydroxy and methoxy groups on benzene ring, the NMR measurements were conducted in DMSO- $d_{6}$. But unfortunately the proton signals of hydroxy groups could not be observed in this case. It is difficult to decide the position of methoxy and hydroxy group on benzene ring unambiguously due to the heavily substituted nature of the aromatic ring and the absence of long range correlations. Consequently, the structure of compound $\mathbf{1}$ was determined as shown in Figure 1 and $\mathbf{1}$ was named rhinacapyyrolidinone A, which is a previously unknown compound.

Compound 2 was obtained also as purplish amorphous solid. Its molecular formula was decided as $\mathrm{C}_{13} \mathrm{H}_{17} \mathrm{NO}_{7}$ by HRFABMS $m / z 300.1103[\mathrm{M}+\mathrm{H}]^{+}$. The ${ }^{1} \mathrm{H}$ NMR spectrum of 2 was very similar to $\mathbf{1}$ except for appearance of a nonequivalent geminal protons at $\delta_{\mathrm{H}} 2.20(\mathrm{~m}, 1 \mathrm{H}), \delta_{\mathrm{H}} 2.52(\mathrm{dd}, 7.9,13.3,1 \mathrm{H})$ and a methine signal at $\delta_{\mathrm{H}} 4.61(\mathrm{dd}, 8.0,8.8,1 \mathrm{H})$. Furthermore, two $O$-bearing $s p^{3}$-hybridized carbon 
signals at $\delta_{\mathrm{C}} 69.2$ and $\delta_{\mathrm{C}} 91.7$ appeared in the ${ }^{13} \mathrm{C}$ NMR spectrum. The molecular weight of 2 was 16 more than 1 (299 vs 283). These results indicated that $\mathbf{2}$ was hydroxy derivative of $\mathbf{1}$. Detailed assignment of the protons and carbons was accomplished by means of the HSQC, HMBC and NOESY experiments. And then, relative configuration of hydroxy group connected to C-3 was considered by NOESY. But unfortunately none of NOE correlations of methine proton $\left(\delta_{\mathrm{H}} 4.61\right.$, dd, 8.0, 8.8, $\left.1 \mathrm{H}\right)$ attributed at $\mathrm{H}-3$ were observed obviously in this experiment. Therefore, it is difficult to elucidate the relative configuration of hydroxy group connect with C-3. Consequently, the structure of compound 2 elucidated as shown in Figure 1 and $\mathbf{2}$ was named rhinacapyrrolidinone B, which is also unknown compound.<smiles>COc1cc(N2C(=O)CC[C@H]2OC)c(OC)c(O)c1O</smiles>

Compound 1<smiles>COc1cc(N2C(=O)[C@H](O)C[C@H]2OC)c(OC)c(O)c1O</smiles>

Compound 2

Figure 1. The structures of isolated compounds from Rhinacanthus nasutus



Compound 1

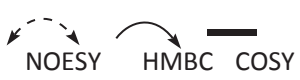

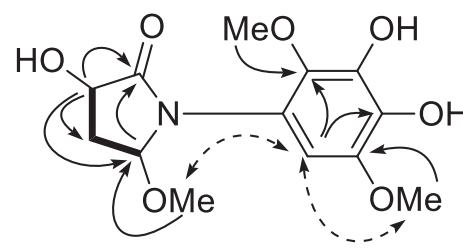

Compound 2

Key correlations

Figure 2. COSY, HMBC and NOESY correlations of $\mathbf{1}$ and $\mathbf{2}$

DPPH radical scavenging activities of isolates were examined according to published methods. ${ }^{11,12} \mathbf{1}$ and 2 showed potent scavenging activities toward the DPPH radical with $50 \%$ effective concentration $\left(\mathrm{EC}_{50}\right)$ values of 109 and $137 \mu \mathrm{M}$, respectively. Trolox, used as a positive control, had an EC 50 value of $130 \mu \mathrm{M}$. Furthermore, these isolates showed little or no detectable cytotoxicity against oral squamous cell carcinoma (HSC-3 and HSC-4), keratinocyte (HaCaT) and normal oral cells (HGF, HPC and HPLF) $\left(\mathrm{CC}_{50}>400 \mu \mathrm{M}\right)$, in contrast to doxorubicin used as positive control that showed excellent cytotoxicity against human oral squamous cell cariconoma $\left(\mathrm{CC}_{50}<0.625 \mu \mathrm{M}\right)$ but not against human oral cells $\left(\mathrm{CC}_{50}\right.$ $>13.5 \mu \mathrm{M}$ ) giving tumor-selectivity index of $>21.7$ ). 
Table 1. ${ }^{1} \mathrm{H}$ and ${ }^{13} \mathrm{C}$ NMR spectral data of compound $\mathbf{1}$ and $\mathbf{2}$

\begin{tabular}{|c|c|c|c|c|}
\hline \multirow[t]{2}{*}{ position } & \multicolumn{2}{|l|}{1} & \multicolumn{2}{|l|}{2} \\
\hline & $\delta_{H}(J$ in $\mathrm{Hz})$ & $\delta_{c}$ & $\delta_{H}(J$ in $\mathrm{Hz})$ & $\delta_{\mathrm{C}}$ \\
\hline 2 & & $178.2(\mathrm{~s})$ & & $177.8(\mathrm{~s})$ \\
\hline \multirow[t]{2}{*}{3} & $2.10(\mathrm{dd}, 2.0,10.7)$ & $26.5(t)$ & $4.61(\mathrm{dd}, 8.0,8.8)$ & $69.2(d)$ \\
\hline & $2.40 *$ & & & \\
\hline \multirow[t]{2}{*}{4} & $2.40 * *$ & $30.2(t)$ & $2.20(\mathrm{~m})$ & $37.2(t)$ \\
\hline & $2.65(\mathrm{~m})$ & & $2.52(\mathrm{dd}, 7.9,13.3)$ & \\
\hline 5 & $5.28(\mathrm{dd}, 1.2,4.8)$ & $94.7(d)$ & 5.27 (d-like, 6.0) & $91.7(d)$ \\
\hline 6 & & $115.7(\mathrm{~s})$ & & $116.0(\mathrm{~s})$ \\
\hline 7 & & $142.5(\mathrm{~s})$ & & $142.4(s)$ \\
\hline 8 & & $141.9(\mathrm{~s})$ & & $141.9(\mathrm{~s})$ \\
\hline 9 & & $138.3(\mathrm{~s})$ & & $138.4(\mathrm{~s})$ \\
\hline 10 & & $142.9(\mathrm{~s})$ & & $142.9(\mathrm{~s})$ \\
\hline 11 & $6.54(\mathrm{~s})$ & $109.0(d)$ & $6.55(\mathrm{~s})$ & $108.3(d)$ \\
\hline 5-OMe & $3.24(s)$ & $56.0(q)$ & $3.25(\mathrm{~s})$ & $56.6(q)$ \\
\hline 7-OMe & 3.82 (s) & $61.3(q)$ & $3.82(\mathrm{~s})$ & $61.2(q)$ \\
\hline 10-OMe & $3.77(\mathrm{~s})$ & $57.4(q)$ & $3.77(\mathrm{~s})$ & $57.5(q)$ \\
\hline
\end{tabular}

\section{EXPERIMENTAL}

General. ${ }^{1} \mathrm{H}$ and ${ }^{13} \mathrm{C}$ NMR spectra were measured on a $400 \mathrm{MHz}$ Agilent-400MR-vnmrs 400 spectrometer (Agilent) in $\mathrm{MeOH}-d_{4}$ at room temperature. MS were recorded on a JMS-700 MStation (JEOL). Optical rotations was measured in $\mathrm{MeOH}$ on a P-2300 (JASCO). Column chromatography was carried out on Diaion HP-20 (NIPPON RENSUI Co.), TOYOPEAL HW40C (TOSOH). HPLC analysis was conducted with a Shimadzu LC20A system comprised of a quaternary solvent delivery system, an on-line degasser, a column temperature controller, and photo diode array detector coupled with an analytical workstation. A SSC-3461 pump (Senshu Scientific Co., Ltd.) equipped with SPD-6A (Shimadzu) was used for preparation of components.

Plant material. The root of $R$. nasutus was supplied from the Chiayi Grass-Produce Cooperation Farm (Chiayi County, Taiwan, ROC) during the autumn of 2009. This specimen was identified by Professor Y. Shirataki and a voucher specimen (\#201006060) was also deposited at the Medicinal Plant Garden of Josai University, Japan.

Extraction and isolation. The roots $(1.2 \mathrm{~kg})$ of $R$. nasutus was extracted with $\mathrm{MeOH}$ three times under reflux for $3 \mathrm{~h}$. The methanolic extract ( $83 \mathrm{~g}$ ) was suspended in water, then partitioned with $n$-hexane, EtOAc and $n$ - $\mathrm{BuOH}$ successively. The $n$ - $\mathrm{BuOH}$ soluble portion was evaporated in vacuo to yield $n$ $\mathrm{BuOH}$ fraction $(24 \mathrm{~g})$. A part of $n-\mathrm{BuOH}$ fraction (10 g) was passed through a Diaion HP-20 column eluted successively with water, $50 \%$ aqueous $\mathrm{MeOH}$ and $\mathrm{MeOH}$. The former elution was condensed in 
vacuo to give the $50 \%$ aqueous methanolic fraction. This fraction (1.9 g) was chromatographed on TOYOPEAL HW40C eluting with 50\% aqueous $\mathrm{MeOH}$ to afford seven fractions (Fr. 1; $67 \mathrm{mg},-2 ; 231$ $\mathrm{mg},-3 ; 1.1 \mathrm{~g},-4 ; 124 \mathrm{mg},-5 ; 90 \mathrm{mg},-6 ; 18 \mathrm{mg},-7 ; 42 \mathrm{mg})$. Fr. 3 (1.1 g) was further purified using silica gel column by gradient elution with $\mathrm{CHCl}_{3}-\mathrm{MeOH}$ mixture $\left(\mathrm{CHCl}_{3}-\mathrm{MeOH}=20: 1 \rightarrow 10: 1 \rightarrow 5: 1 \rightarrow 1: 1\right)$ to give four fractions (Fr. 3-1, -2, -3 and -4). Fr. 3-1 (216 mg) was purified with reversed phase HPLC (Senshu Pak ODS $150 \mathrm{~mm} \times 10 \mathrm{~mm}$, water-MeCN = 82:18, $3.0 \mathrm{~mL} / \mathrm{min}$, isocratic, UV at $254 \mathrm{~nm}$ ) to obtain compound $\mathbf{1}(8.80 \mathrm{mg})$ and $\mathbf{2}(4.87 \mathrm{mg})$.

Compound 1: bluish amorphous solid; $[\alpha]_{\mathrm{D}}{ }^{20}+1.56(\mathrm{MeOH}, \mathrm{c} 0.56) ; \mathrm{UV}(\mathrm{MeOH}) \lambda \max (\log \varepsilon) 288 ;{ }^{1} \mathrm{H}$ NMR (400 MHz, CD $\left.{ }_{3} \mathrm{OD}\right)$ and ${ }^{13} \mathrm{C}$ NMR (100 MHz, CD $\left.\mathrm{OD}\right)$ spectroscopic data are listed in Table 1. HRFABMS $m / z 284.1138[\mathrm{M}+\mathrm{H}]^{+}$(calcd. for $\mathrm{C}_{13} \mathrm{H}_{18} \mathrm{NO}_{6}, 284.1134$ ).

Compound 2: purplish amorphous solid; $[\alpha]_{\mathrm{D}}{ }^{20}+1.71(\mathrm{MeOH}, \mathrm{c} 0.28)$; UV $(\mathrm{MeOH}) \lambda \max (\log \varepsilon) 288$; ${ }^{1} \mathrm{H}$ NMR (400 MHz, CD $\left.{ }_{3} \mathrm{OD}\right)$ and ${ }^{13} \mathrm{C}$ NMR (100 MHz, CD $\left.{ }_{3} \mathrm{OD}\right)$ spectroscopic data are listed in Table 1. HRFABMS m/z $300.1103[\mathrm{M}+\mathrm{H}]^{+}$(calcd. for $\mathrm{C}_{13} \mathrm{H}_{18} \mathrm{NO}_{7}, 300.1083$ ).

2,2-Diphenyl-1-picrylhydrazyl Radical (DPPH) Scavenging Capacity Assay. Isolated compounds were determined by DPPH test according to procedure previously reported. Briefly $5 \mu \mathrm{L}$ of various concentrations of each isolate in ethanol solution was added to $95 \mu \mathrm{L}$ of DPPH solution $(0.4 \mathrm{mg} / \mathrm{mL}$ in $\mathrm{EtOH})$. The mixtures were kept in the dark for $10 \mathrm{~min}$ at room temperature and the decrease in absorbance was measured at $525 \mathrm{~nm}$ against a blank consisting of an equal volume of EtOH by microplate reader. Trolox was used as a positive control. All samples were run in duplicate.

Cell culture. HSC-3 and HSC-4 cells (Rika Cell Bank, Tsukuba, Japan), spontaneously immortalized HaCaT keratinocytes derived from adult human skin (CLS Cell Lines Service GmbH, Eppelheim, Germany) and human oral cells (HGF, HPC, HPLC) (5-15 population doubling level) established from the extracted first premolar tooth in the lower jaw and periodontal tissues of a 12 -year-old girl ${ }^{15}$ were cultured at $37{ }^{\circ} \mathrm{C}$ in DMEM supplemented with $10 \%$ heat-inactivated FBS, 100 units $/ \mathrm{mL}$, penicillin G and $100 \mu \mathrm{g} / \mathrm{mL}$ streptomycin sulfate under a humidified atmosphere with $5 \% \mathrm{CO}_{2}$.

Assay for cytotoxic activity. Cells were trypsinized and inoculated at $2.5 \times 10^{3}$ cells or $1: 3$ split ratio (only for normal cells) in 96-microwell plates and incubated for $48 \mathrm{~h}$ to allow complete attachment. Near confluent cells were then incubated for $48 \mathrm{~h}$ in fresh culture medium without (control) or with serially diluted samples. The viable cell number was determined by MTT method. ${ }^{15}$

\section{REFERENCES}

1. N. Motohashi, 'Nutraceuticals in Rhinacanthus nasutus (Hattkaku-reishi-soh): Dietary Fiber, Fruit and Vegetable Consumption and Health,' ed. by F. Klein and G. Möller, Nova Science Publishers, Inc., New York, 2010, pp. 119-156. 
2. P. Siripong, J. Yahuafai, S. Piyavuruyakul, C. Hahnvajanawong, S. Piyaviriyakul, N. Oku, K. Kanokmedhakul, N. Kongkathip, and S. Ruchirawat, Biol. Pharm. Bull., 2009, 32, 1251.

3. P. Siripong, S. Piyavuruyakul, J. Yahuafai, R. Chanpai, K. Kanokmedhakul, S. Ruchirawat, and N. Oku, J. Trad. Med., 2006, 23, 166.

4. N. Siriwatanametanon, B. L, Fiebich, T, Efferth, J. M. Prieto, and M. Heinrich, J. Ethnopharmacol., 2010, 130, 196.

5. T.-S. Wu, H.-C. Hsu, P.-L. Wu, C.-M. Teng, and Y.-C. Wu, Phytochemistry, 1998, 49, 2001.

6. S. Ikeda, Farumashia, 1997, 33, 778 (in Japanese).

7. S. Tewtrakul, P. Tansakul, and P. Panichayupakaranant, Phytomedicine, 2009, 16, 929.

8. S. Tewtrakul, P. Tansakul, and P. Panichayupakaranant, Phytomedicine, 2009, 16, 581.

9. K. Punturee, C. P. Wild, and U. Vinitketkumneun, J. Ethnopharmacol., 2004, 95, 183.

10. H. Horii, R. Suzuki, H. Sakagami, M. Tomomura, A. Tomomura, and Y. Shirataki, Anticancer Res., 2013, 33, 453.

11. A. Nakamura, Tokyo Kasei Gakuin Daigaku Kiyo, 2004, 44, 5.

12. S. K. Sadhu, E. Okuyama, H. Fujimoto, and M. Ishibashi, Chem. Pharm. Bull., 2003, 51, 595.

13. T. Ohta, H. Inoue, G. Kusano, and Y. Oshima, Heterocycles, 1998, 47, 883.

14. K. H. Kim, I. K. Lee, K. M. Park, W. K. Kim, and K. R. Lee, Bull. Korean Chem. Soc., 2008, 29, 1591.

15 K. Kantoh, M. Ono, Y. Nakamura, Y. Nakamura, K. Hashimoto, H. Sakagami, and H. Wakabayashi, In Vivo, 2010, 24, 843. 